\title{
DAMPAK PARTISIPASI ORANGTUA DAN MOTIVASI BELAJAR TERHADAP PRESTASI BELAJAR SISWA PADA SMU KRISTEN DIAKUI MAKASSAR
}

\section{(Polikarpus Ka'pan)}

\begin{abstract}
Abstrak
Pada era globalisasi ini terjadi kemajuan diberbagai sendi kehidupan manusia yang sudah sangat maju, khusus pada bidang pendidikan. Boleh dikatakan bahwa tidak ada lagi kelurahan yang tidak punya sekolah. Di kota-kota besar berdiri berbagai jenis pendidikan baik yang dikelolah oleh Negara maupun swasta bahkan ada pendidikan yang dikeloah oleh Asing atau yang bertaraf Internasional. Sarana dan prasarana disiapkan untuk memberikan kenyamana dan kemudahan bagi peserta didik dalam menyerap pelajaran. Namun keberhasilan siswa dalam meraih prestasi masih sangat jauh dari harapan seperti tergambar pada hasil Ujian Nasional. Karna itu sangatlah diharapkan peran serta setiap orang tua dalam mendampingi serta memberikan motivasi kepada anak-anaknya sehinga prestasi yang diharapkan dapat tercapai.

Oleh sebab itulah melalui tulisan ini akan dipaparkan tentang partisipasi orang tua dalam mencapai prestasi anak
\end{abstract}

Kata Kunci: Partisipasi, Orangtua, motivasi dan prestasi.

\section{A. Latar Belakang}

Pada dasawarsa ini perkembangan Iptek maju dengan sangat pesat, sehingga menyebabkan perubahan terjadi di segala bidang kehidupan. Sejalan dengan itu tuntutan masyarakat akan kualitas pendidikan sangat besar. Sebab hanya pendidikan yang berkualitas yang diharapkan mampu menghadapi berbagai perubahan dan tantangan pada era yang sedang mendunia. Karena itu kualitas sumber daya manusia merupakan salah satu faktor penting dalam membangun bangsa.

Oleh karena itu pendidikan mempunyai tugas dan posisi strategis dalam menyiapkan sumber daya manusia yang berkualitas. Sumber daya manusia yang berkualitas adalah manusia yang beriman kepada Tuhan Yang maha Esa dan menguasai Iptek

Berkaitan dengan itu, dalam rangka mempersiapkan sumber daya manusia yang berkualitas, maka yang perlu dilakukan adalah meningkatkan mutu pendidikan. Mutu pendidikan tidak terpelepas dari hasil atau prestasi belajar mengajar. Secara umum hasil proses belajar mengajar selama ini masih tergolong rendah termasuk pada SMU Kristen Makassar. Hal tersebut merupakan pembicaraan pada berbagai kalangan, baik praktisi pendidikan maupun masyarakat pada umumnya. Walaupun demikian berbagai upaya telah dilakukan untuk meningkatkan mutu pendidikan, namun belum menunjukkan hasil yang memuaskan.

Rendahnya mutu pendidikan merupakan masalah besar yang melanda dunia pendidikan pada umumnya. Zamroni (2001:182) menjelaskan bahwa faktor mendasar dalam kaitannya dengan mutu pendidikan adalah lebih disebabkan intres keluarga dan motivasi berprestasi di kelas rendah. Rendahnya motivasi berprestasi lebih disebabkan oleh rendahnya motivasi belajar. Pencapaian prestasi belajar siswa, dalam kajian ini dapat ditinjau dari segi 
manajemen pendidikan. Akibat prestasi belajar siswa rendah, dan bahkan terdapat gejala penurunan seperti dewasa ini, menunjukkan adanya permasalahan dalam pengelolaan, khususnya pada SMU Kristen Makassar.

Memperhatikan kondisi demikian, proses belajar mengajar siswa pada SMU Kristen Makassar perlu mendapat perhatian dari semua pihak yang terkait dalam proses pendidikan. Kualitas pendidikan yang didasarkan atas kemampuan belajar siswa ini tidak terlepas dari lingkungan keluarga, sekolah atau masyarakat pada umumnya. Berdasarkan undang-undang nomor 2 tahun 1989 pasal 10 dinyatakan bahwa: Penyelenggaraan pendidikan dilaksanakan melalui dua jalur yaitu pendidikan sekolah dan jalur pendidikan luar sekolah;jalur pendidikan sekolah merupakan pendidikan yang diselenggarakan di sekolah melalui kegiatan belajar mengajar secara berjenjang dan berkesinambungan; jalur pendidikan luar sekolah merupakan pendidikan yang diselenggarakan di luar sekolah melalui kegiatan belajar mengajar yang tidak harus berjenjang dan berkesinambungan; Pendidikan keluarga merupakan bagian dari jalur pendidikan luar sekolah yang diselenggarakan dalam keluarga dan yang memberi keyakinan agama, nilai budaya, nilai moral dan keterampilan.

Kedua jalur itulah yang bertanggungjawab akan kelangsungan pendidikan anak dalam rangka mewujudkan cita-cita bangsa yaitu manusia Indonesia seutuhnya. Keluarga sebagai jalur pendidikan luar sekolah merupakan lingkungan pendidikan pertama dan utama bagi anak untuk meletakkan dasar pendidikan dengan menanamkan nilai, agama, moral dan pengetahuan lainnya. Zakiah Drajad (1995:47) menjelaskan bahwa keluarga adalah wadah pertama dan utama bagi pertumbuhan dan perkembangan anak, dengan demikian peran keluarga ditinjau dari segi pendidikan merupakan satu kesatuan hidup yang menyediakan situasi dan menanamkan system belajar bagi anak.

Dengan demikian keluarga merupakan salah satu lembaga yang mengemban tugas dan tanggungjawab dalam pencapaian tujuan pendidikan. Itu sebabnya keluarga sebagai lingkungan pendidikan, diharapkan mampu mengelola pendidikan anak sedemikian rupa, agar dapat berhasil sesuai dengan yang diharapkan. Menurut Burhanuddin (1994) bahwa pengelolaan setiap kegiatan manusia baik dalam organisasi formal maupun non formal dalam Pencapaian tujuan perlu adanya penerapan sistem kerja manajemen ke dalam unsur-unsur kegiatan dalam segala bidang, termasuk pendidikan dalam lingkungan keluarga.

Oleh karena itu pengelolaan pendidikan dalam lingkungan keluarga juga harus disesuaikan dengan konsep manajemen. Dengan demikian konsep manajemen dalam lingkungan keluarga dapat diwujudkan dengan merencanakan kebutuhan belajar, mengarahkan kegiatan belajar dan mengendalikan hasil kegiatan belajar anak termasuk menjalin hubungan dengan pihak sekolah. Hal tersebut merupakan bentuk dari partisipasi orang tua dalam pendidikan anaknya dengan menyediakan sarana dan prasarana, menciptakan situasi yang kondusif, memberikan bimbingan, dorongan, mengadakan hubungan dan kerja sama dengan guru, sekolah dan sebagainya. Dengan demikian kegiatan belajar anak dapat terkontrol sehingga dapat berprestasi yang optimal.

Hasil penelitian Hobson yang dikutip Suprat (2000) bahwa ada korelasi positif yang signifikan antara keterlibatan, kewibawaan orang tua di dalam kegiatan sekolah dengan keberhasilan peserta didik. Hal tersebut menunjukkan bahwa partisipasi orang tua dalam kegiatan belajar akan besar pengaruhnya terhadap keberhasilan pendidikan anak. Oleh karena itu partisipasi atau keterlibatan orang tua dalam pelaksanaan pendidikan anak mutlak 
diperlukan. Namun kondisi yang dijumpai di lapangan menunjukkan bahwa keterlibatan orang tua terhadap pendidikan anak hingga kini masih kurang mendapat perhatian. Hal tersebut didukung hasil penelitian Buchori, yang dikutip oleh Pidarta (1997) yang menunjukkan bahwa pendidikan yang ditangani sampai sekarang baru pendidikan jalur sekolah termasuk pendidikan keluarga dapat dikatakan belum tersentuh.

Kenyataan ini nampak dari orang tua yang menyerahkan dan mempercayakan pendidikan anak sepenuhnya pada sekolah, seakan tanggungjawab pendidikan adalah hanya pihak sekolah. Sebagian dari mereka beranggapan bahwa urusan kualitas atau mutu pendidikan anak bukan merupakan tanggungjawab mereka.

Selain faktor partisipasi orang tua yang mempengaruhi prestasi belajar anak adalah kondisi internal siswa yaitu mengenai motivasi belajar. Tanpa ada motivasi belajar, sulit bagi anak untuk mendapatkan hasil yang optimal. Faktor motivasi belajar memegang peranan penting dalam keberhasilan belajar, karena faktor ini yang menimbulkan prilaku belajar untuk mencapai prestasi, sehingga hasil belajar siswa akan lebih optimal. Dengan motivasi inilah yang menjadikan siswa mempunyai banyak energi untuk belajar lebih tekun, disiplin, rajin mengerjakan tugas-tugas dan mengulangi pelajaran yang telah diperoleh dari sekolah. Siswa yang mempunyai motivasi belajar tinggi kemungkinan keberhasilannya juga sangat tinggi. Sebaliknya jika motivasi belajar rendah kemungkinan untuk berhasil dalam pendidikannya juga rendah.

Berdasarkan uraian tersebut yang mempengaruhi prestasi belajar adalah partisipasi orang tua dan motivasi belajar siswa. Oleh karena itu penulis tertarik melakukan penelitian untuk mengetahui seberapa besar partisipasi orang tua dan motivasi belajar mempengaruhi prestasi belajar siswa SMU Kristen Makassar.

\section{B. Rumusan Masalah}

Berdasarkan latar belakang di atas, maka dapat dirumuskan permasalahan sebagai berikut:

1. Bagaimanagambaran tingkat partisipasi orang tua, tingkat motivasi belajar siswa dan tingkat prestasi belajar siswa SMU Kristen Makassar

2. Apakah ada pengaruh yang signifikan tingkat partisipasi orang tua dan tingkat motivasi belajar siswa terhadap prestasi belajar siswa SMU Kristen Makassar

\section{TINJAUAN PUSTAKA \\ Prestasi Belajar}

\section{a. Hakekat dan Pengertian Prestasi Belajar}

Konsep prestasi pada dasarnya merupakan hasil kinerja seseorang dalam memecahkan suatu permasalahan, baik permasalahan yang berhubungan dengan pendidikan, belajar, usaha maupun hal-hal yang sejenis.

Hasil belajar siswa pada hakekatnya adalah perubahan tingkah laku dalam arti luas yang mencakup aspek kognetif, afektif dan psikomotor. Menurut Woodworth dan Maquis dalam Subandiyah (1996:193) mengatakan bahwa prestasi merupakan hasil yang berupa kecakapan nyata yang dapat diukur secara langsung dengan menggunakan tes. Selanjutnya Webster 
mengatakan bahwa prestasi adalah penampilan pencapaian seseorang peserta didik dalam suatu bidang studi, berupa kualitas dan kuantitas hasil kerja atau kinerja peserta didik selama priode waktu yang telah ditentukan yang diukur dengan tes standar.

Pendapat lain mengenai hasil belajar seperti yang dikemukakan oleh Briggs yang dikutip oleh Bukka (2000) merumuskan hasil sebagai yang dikenal dengan sebutan academic achievement adalah keseluruhan kecakapan dan hasil yang dicapai melalui proses belajar mengajar di sekolah yang dinyatakan dengan angka-angka atau nilai-nilai yang diukur dengan tes hasil belajar. Hal yang sama dikemukakan oleh Wiliam W. (1992) mendefinisikan hasil belajar sebagai kemampuan actual yang dapat diukur secara langsung dengan tes.

Berdasarkan Uraian di atas maka prestasi belajar dapat diartikan sebagai hasil belajar yang diperoleh dari kegiatan belajar siswa di sekolah pada suatu mata pelajaran dalam waktu tertentu yaitu pada catur wulan satu tahun 2001/2002.

Howard Kingsley dalam Sujana (1995) membagi hasil belajar menjadi tiga macam yaitu: 1) Keterampilan dan kebiasaan; 2) Pengetahuan dan pengertian; 3) Sikap dan cita-cita. Sedangkan Gagne membagi hasil belajar kedalam lima kategori yaitu: 1) Informasi verbal;2) Ketrerampilan intelektual;3) Strategi kognetif; 4) sikap dan; 5) Keterampilan motoris.

\section{b.Faktor-Faktor Yang Mempengaruhi Belajar}

Prestasi belajar merupakan hasil dari suatu sistem pendidikan, sehingga tingkat keberhasilannya ditentukan dan dipengaruhi oleh elemen-elemen dari sistem itu sendiri seperti raw input, instrumental input dan environmental input. Raw input meliputi kondisi fisiologis dan psikologis siswa, perangkat keras dan perangkat lunak sebagai instrumental input dan lingkungan alam, lingkungan sosial dan proses belajar mengajarnya itu sendiri sebagai environmental input.

Menurut Abdullah (1985) Prestasi Belajar merupakan indikator keberhasilan atau kualitas dan pengetahuan yang telah dikuasai siswa. Munandar (1999) mengatakan bahwa prestasi seseorang tergantung dari motivasi dari dalam dirinya untuk berprestasi, sikap pribadinya dan tingkat kecerdasannya. Beliau selanjutnya mengatakan bahwa prestasi merupakan perwujudan dari bakat dan kemampuan, dimana bakat diartikan sebagai kemampuan bawaan yang masih perlu dikembangkan dan dilatih agar dapat terwujud. Sedangkan kemampuandiartikansebagai daya untuk melakukan suatu tindakan sebagai hasil dari pembawaan.

Pengertian tersebut mengandung makna bahwa orang yang berbakat belum tentu selalu memperoleh prestasi yang tinggi. Akan tetapi sejauh mana bakat tersebut didukung oleh faktor-faktor lain sehingga bakat tersebut akan terwujud mencapai prestsi yang tinggi. Faktor-faktor tersebut sebagian dipengaruhi oleh lingkungan maupun dari dalam diri sendiri. Faktor lingkungan seperti kesempatan, partisipasi atau dukungan orang tua, lingkungan masyarakat. Sedangkan yang dari dalam diri seperti minat, keinginan untuk berprestasi, ulet dalam mengatasi masalah yang sulit dan lain-lain.

Berbagai pendapat mengenai banyaknya faktor yang mempengaruhi belajar. Akan tetapi pada dasarnya semua tidak berbeda secara prinsip. Secara garis besar Suryabrata (1993:249) membedakan faktor yang mempengaruhi belajar siswa menjadi dua yaitu: faktor dari dalam dan faktor dari luar siswa. 
1). Faktor yang berasal dari luar siswa.

Faktor dari luar yaitu faktor sosial dan non sosial. Adapun faktor sosial meliputi lingkungan keluarga termasuk cara mendidik, suasana rumah, masyarakat, teman, guru dan staf sekolah, sedang yang termasuk aspek non sosial adalah letak rumah, letak sekolah, keadaan alam sekitarnya dan lain-lain.

2). Faktor yang berasal dari siswa, yakni aspek fisiologis dan psikologis.

Adapun aspek fisiologis adalah meliputih tonus jasmani, mata, telinga dan lain-lain. Sedangkan aspek psikologis adalah intelegensi, sikap, dan bakat, konsentrasi serta motivasi.

Motivasi Belajar

Pada dasarnya motivasi digerakkan atas dasar keinginan dan kebutuhan. Buck (1988) berpendapat bahwa motivasi manusia didasarkan atas dorongan, keinginan dan kekuatan, dimana ketiganya biasanya disebut dengan kebutuhan. Kemudian Koeswara (1989) dan Siagian (1995) Menyatakan bahwa di dalam motivasi terkandung adanya keinginan yang mengaktifkan atau mengerakkan, menyalurkan dan mengarahkan sikap dan prilaku individu belajar yang dikaitkan dengan pencapaian tujuan baik individu maupun kelompok.

Dengan Uraian di atas, maka motivasi dapat dilihat dari tiga hal yaitu adanya kebutuhan, dorongan dan tujuan. Kebutuhan, merupakan segi pertama dari motivasi akan muncul dalam diri seseorang apabila merasa ada kekurangan pada dirinya, atau dapat diartikan kebutuhan akan muncul apabila dirasakan ada ketidaseimbangan antara apa yang dimiliki dan yang diharapkan.

Motivasi sebagai dorongan, menurut teori Woodworth tanpa ada dorongan maka tidak ada kekuatan yang mengerakkan dan mengarahkan mekanisme yang bertindak sebagai penggerak munculnya tingkah laku. Dorongan memiliki tiga karakteristik yaitu intensitas, arah dan pretensi, Koeswara (1989).

Selanjutnya pendapat Hull dalam Petri (1981) Menyatakan dorongan atau motivasi berkembang untuk memenuhi kebutuhan organisme. Di samping itu merupakan sistem yang memungkinkan organisme memelihara kelangsungan hidupnya. Kebutuhan -kebutuhan organisme merupakan Penyebab munculnya dorongan, dan dorongan akan mengaktifkan tingkah laku mengembalikan keseimbangan fisiologis organisme. Pendekatan pada teori Hull adalah dorongan sebagai motivasi penggerak utama prilaku.

Peranannya sebagai penumbuh gairah, merasa senang dan semangat untuk belajar, sehingga apabila siswa mempunyai motivasi belajar tinggi maka akan mengerahkan segala usahanya untuk mencapai tujuan. Sehingga diduga anak yang motivasi belajarnya tinggi kemungkinan akan memperoleh prestasi tinggi pula.

Pengertian Motivasi Belajar

Belajar merupakan kegiatan yang mendasar dari proses pendidikan. Sesuai dengan pendapat Muhibbin Syah (2000:89) bahwa belajar adalah kegiatan yang berproses dan merupakan unsur yang sangat fundamental dalam setiap penyelenggaraan jenis dan jenjang pendidikan. Hal ini menunjukkan bahwa gagal atau berhasilnya pencapaian tujuan pendidikan banyak tergantung dari proses belajar yang dialami siswa baik di sekolah maupun di rumah. Belajar bukan hanya monopoli dunia persekolahan, melainkan merupakan masalah setiap manusia yang ingin berhasil dalam hidupnya. Hal ini karena pada dasarnya setiap manusia memiliki kebutuhan dan karakteristik yang berbeda-beda. 
Belajar menurut Lesterd \& Alice Crow dalam Roestiyah (1989): 141) ialah perubahan individu dalam kebiasaan, pengetahuan dan sikap. Dalam pengertian ini seseorang belajar, kalau ada perubahan dari tidak tahu menjadi tahu dalam menguasai ilmu pengetahuan. Ini berarti belajar merupakan suatu proses dimana guru melihat apa yang terjadi selama murid menjalani pengalaman edukatif dalam mencapai suatu tujuan.

Motivasi berasal dari bahasa latin "movere" yang Artinya mengerakkan (to move). Istilah tersebut dikalangan ahli-ahli psikologis didefinisikan sebagai gejala yang meliputi dorongan prilaku mencari tujuan pribadi, kecenderungan untuk melakukan kegiatan yang berawal dari stimulus atau dorongan yang kuat dan berakhir dengan respon penyesuaian yang tepat; membangun, mengatur dan menunjang pola prilaku (Sahabuddin 1999:146). Sebagaimana pendapat Donoseputro (1983) bahwa motivasi adalah kemajuan untuk berbuat. Kemauan di sini dapat dipahami sebagai keinginan belajar tanpa adanya dorongan dari luar.

Sementara pandangan Chauhan dalam Djalali (1994) motivasi adalah suatu proses yang menyebabkan timbulnya aktivitas pada organisme sehingga terjadi suatu prilaku. Lebih lanjut Stoner, J. A et.al (1996:134) motivasi adalah karakteristik psikologis manusia yang memberi kontribusi pada tingkat komitmen seseorang. Termasuk di dalamnya faktor-faktor yang menyebabkan, menyalurkan dan mempertahankan tingkah aku manusia dalam arah tekad tertentu. Pendapat lain, motivasi diartikan sebagai keadaan dalam pribadi seseorang yang mendorong keinginan individu untuk melakukan kegiatan -kegiatan tertentu guna mencapai tujuan, Handoko, (1999:252). Dimana motivasi merupakan kekuatan pendorong yang akan mewujudkan prilaku guna mencapai tujuan kepuasan diri. Atau dapat dikatakan bahwa prilaku motivasi cenderung berlangsung terus sampai tujuan tercapai atau sampai pada munculnya motivasi.

Motivasi dapat dibedakan menjadi dua macam, yaitu motivasi intrinsic dan motivasi ektrinsik. Motivasi Intrinsik adalah motivasi yang timbul dari dalam diri seseorang, karena setiap individu sudah ada dorongan untuk melakukan sesuatu tanpa dorongan dari luar. Dalam hal kegiatan belajar, motivasi intrinsic dapat dikatakan sebagai bentuk motivasi yang di dalam aktivitas belajar dimulai dan dirumuskan Berdasarkan suatu dorongan dari dalam diri yang secara mutlak berkaitan dengan kegiatan belajar.

Motivasi ektrinsik adalah motif yang aktif dan berfungsinya karena adanya rangsangan dari luar. Oleh karena itu motif ektrinsik dapat dikatakan sebagai bentuk motivasi yang di dalam aktifitas belajarnya dimulai dan diteruskan berdasarkan dorongan dari luar dan tidak secara mutlak Berkaitan dengan kegiatan belajar. Menurut pendapat Winskel (1987) motivasi belajar adalah keseluruhan daya penggerak psikis di dalam diri siswa yang menimbulkan kegiatan belajar dan menjamin kelangsungan kegiatan belajar demi tercapainya tujuan.

Berdasarkan uraian sebelumnya, maka motivasi belajar dapat diartikan sebagai dorongan atau kekuatan daya penggerak siswa baik dari luar maupun dari dalam yang menimbulkan kegiatan belajar, yang mengarah kepada kelangsungan belajar dalam pencapaian tujuan yang diinginkan.

\section{Pengertian Partisipasi Orang Tua}

\section{Partisipasi orang Tua}

Partisipasi berasal dari kata "part" Artinya bagian dan "capere" berarti mengambil. Jadi partisipasi berarti mengambil bagian atau ikut serta dalam mengambil bagian atau dapat juga disebut peran serta atau keterlibatan. 
Partisipasi pada dasarnya tidak terlepas dengan konsep manajemen. Oleh karena itu dalam manajemen, partisipasi sering dikaitkan dengan keikutsertaan dalam proses pengambilan keputusan, baik keikutsertaannya dalam pengambilan keputusan maupun dalam implementasi. Ini berarti konsep partisipasi dapat berupa keikutsertaan dalam proses perencanaan, pelaksanaan, penggerakan dan pengendalian serta ikut memikul tanggung jawab dalam mencapai tujuan. Di samping itu partisipasi juga menyangkut memberikan saran, ide atau bahkan kerja sama dari semua unsur yang terkait dalam suatu organisasi.

Selanjutnya pengertian partisipasi menurut Ensklopedi Pendidikan adalah suatu gejala demokratis di mana orang diikutsertakan dalam perencanaan serta pelaksanaan dan juga ikut memikul tanggungjawab sesuai dengan kematangan dan tingkat kewajibannya. Partisipasi itu menjadi lebih baik dalam bidang-bidang fisik maupun bidang mental serta penentuan kebijakan dalam Suryobronto (1997:279).

Berdasarkan pengertian tersebut, maka yang dimaksud dengan partisipasi adalah suatu proses keikutsertaan seseorang dalam bentuk perencanaan, pelaksanaan, kerjasama dan tanggungjawab baik secara fisik maupun mental.

\section{Bentuk dan Tingkat Partisipasi}

Proses belajar siswa pada dasarnya untuk meningkatkan kemampuan baik yang bersifat kognetif, afektif maupun psikomotor. Hal ini merupakan upaya untuk mencapai hasil belajar yang baik. Menurut Cowling dan Philip (1996) bentuk partisipasi dibedakan menjadi tiga yaitu: 1) partisipasi langsung atau individu; 2) partisipasi tidak langsung atau perwakilan dan 3) partisipasi keuangan. Lebih lanjut Abdullah (1990) membedakan partisipasi masyarakat dalam pembangunan dalam tiga jenis, yaitu 1) partisipasi dalam bentuk tenaga; 2) partisipasi dalam bentuk dana dan 3) partisipasi dalam bentuk pemikiran.

Ditinjau dari tingkatannya menurut Jumrowi sebagaimana yang dikutip Subandyah (1990) partisipasi dapat dibedakan menjadi tiga yaitu: partisipasi dalam program perencanaan dan kaitannya dengan program lain; partisipasi dalam pengambilan keputusan dan partisipasi dalam pelaksanaan. Selain itu ada juga yang membedakan dalam kategori tinggi atau rendah dan luas atau sempit.

Berkenaan dengan bentuk dan jenis partisipasi tersebut, maka bentuk partisipasi orang tua dalam pendidikan anak dapat ditinjau dari sejauhmana orang tua merencanakan kebutuhan belajar anak, mengarahkan dan mengendalikan kegiatan belajar serta menjalin hubungan dengan sekolah.

\section{Hubungan Partisipasi Orang Tua dengan Prestasi Belajar Siswa.}

Keterlibatan orang tua dalam melaksanakan kegiatan pendidikan anak sangat penting, karena akan berpengaruh positif bagi keberhasilan dan kemajuan pendidikan anak. Menurut Purwanto (1998) hubungan antara orang tua dengan sekolah akan dapat memperoleh pengetahuan dan pengalaman dari sekolah/guru dalam hal pendidikan anak-anaknya. Selain itu juga akan dapat mengetahui permasalahan-permasalahan yang dihadapi anak baik me4nyangkut kedisiplinan, kerajinan, tingkat kemampuan dan lain-lain. Karena itu kerja sama orang tua dan sekolah sangat Mendukung akan keberhasilan pendidikan anak. 
Orang tua sebagai pendidik sekaligus membimbing, memotivasi, menyuruh, bahkan menegur anak untuk belajar agar dapat berhasil dengan baik. Berkenaan dengan itu pula orang tua perlu membantu kegiatan belajar dan mengevaluasi hasil belajar yang diperoleh anak. Hal-hal tersebut hendaknya menjadi perhatian orang tua, karena partisipasi orang tua mempengaruhi keberhasilan dalam pencapaian tujuan pendidikan anak.

Oleh karena, partisipasi orang tua sangat besar pengaruhnya terhadap keberhasilan pendidikan (prestasi belajar) siswa, maka perlu diupayakan hubungan yang harmonis antara orang tua dan anak. Hubungan yang penuh perhatian, kasih sayang disertai bimbingan, dorongan dan bahkan bila perlu diberi hukuman yang mendidik, sehingga dapat mensukseskan belajar anak.

Dengan demikian dapat dikatakan bahwa kinerja belajar atau prestasi belajar siswa dipengaruhi oleh partisipasi orang tua, melalui keterlibatannya dalam menjalankan tugas dan tanggungjawabnya terhadap kegiatan belajar anak.

\section{c. Kerangka Pemikiran}

Partisipasi belajar pada dasarnya merupakan penguasaan pengetahuan dan ketrampilan yang diperoleh dari lingkungannya. Prestasi belajar bagi siswa adalah hasil belajar yang diperoleh dari kegiatan belajar siswa di sekolah dalam beberapa mata pelajaran dan dalam waktu tertentu yang dapat dilihat dari nilai tes setiap catur wulan.

Partisipasi belajar dipengaruhi oleh dua faktor yaitu dari dalam dan dari luar. Faktor dari luar antara lain partisipasi orang tua dan motivasi belajar merupakan faktor dari dalam diri siswa. Keluarga atau orang tua termasuk dalam lingkungan pendidikan atau dapat dikatakan sebagai lembaga pendidikan, mempunyai tanggung jawab akan keberhasilan pendidikan anaknya. Dalam kegiatan belajar anak, partisipasi orang tua sangat penting. Oleh karena itu keterlibatan orang tua dalam pendidikan anak dapat diwujudkan dengan merencanakan, melaksanakan, dan mengendalikan serta menjalin hubungan kerjasama dengan sekolah agar dapat mencapai prestasi atau hasil belajar yang optimal.

Di samping itu, pendidikan dapat berhasil dengan baik apabila siswa memiliki motivasi belajar yang tinggi, karena motivasi mempunyai peran yang sangat tinggi dalam kegiatan belajar. Oleh karena itu apabila motivasi belajar siswa tinggi dimungkinkan prestasi belajar juga tinggi.

Motivasi dibedakan menjadi dua macam, yaitu motivasi intrinsik dan motivasi ektrinsik. Baik motivasi intrinsik maupun motivasi ektrinsik akan mempengaruhi dorongan untuk belajar. Akan tetapi motivasi intrinsik lebih kuat pengaruhnya Berkaitan dengan kegiatan belajar. Dengan demikian partisipasi orang tua dan motivasi belajar akan berpengaruh terhadap prestasi belajar siswa.

\section{METODE PENELITIAN}

\section{Jenis Penelitian}

Penelitian ini menggunakan pendekatan survei dengan mempelajari sebagian dari populasi atau survei sample. Menurut Kerlinger, (2000:600) penelitian survei adalah mengkaji populasi (universe) yang besar maupun kecil dengan menyeleksi serta mengakji sample yang dipilih dari populasi. Selanjutnya menurut pendapat Ary D. (1985) bahwa survei berusaha 
3. Tingkat prestasi belajar dapat diartikan sebagai hasil belajar yang diperoleh dari keinginan belajar siswa di sekolah dalam beberapa mata pelajaran dan dalam catur wulan 1 (satu) yang dapat dilihat dari nilai murni yang diberikan oleh guru mata pelajaran yang bersangkutan.

\section{Instrumen Penelitian}

Instrumen penelitian menurut Sudjana dan Ibrahim (2001) adalah alat untuk memperoleh Informasi dari sumber data. Sementara menurut Arikunto (1998:151) adalah alat atau falisilitas yang digunakan oleh peneliti dalam mengumpulkan data pekerjaannya lebih mudah dan hasilnya lebih baik, dalam arti lebih cermat, lengkap, dan sistematis sehingga lebih mudah diolah.

Instrumen memegang peranan yang sangat penting dalam menentukan mutu suatu penelitian, karena kesahihan atau validitas data yang diperoleh akan sangat ditentukan oleh kualitas instrumen yang digunakan disamping prosedur pengumpulan data yang ditempuh (Abustam et.al.1996:57)

Pengumpulan data dalam suatu penelitian, seorang peneliti dapat menggunakan instrumen yang telah tersedia dan dapat pula menggunakan instrumen yang dibuat sendiri yang telah dikembangkan untuk menjaring data dari responden yaitu: 1) Instrumen Tingkat Partisipasi Orang Tua; dan 2) Instrumen Tingkat Motivasi Belajar Siswa.

Menurut Sumanto (1995) Instrumen yang baik adalah yang dapat menguji/menilai secara objektif. Ini berarti bahwa nilai atau Informasi yang diberikan individu tidak dipengaruhi oleh yang menilai dan dapat menyajikan data secara valid dan reliabel. Untuk mengetahui tingkat validitas dan reliabilitas (keandalan) instrumen yang dikembangkan, terlebih dahulu dilakukan uji coba sebagai syarat kelayakan suatu instrumen untuk digunakan dalam penelitian. Untuk keperluan tersebut kedua Instrumen yaitu Instrumen Tingkat Partisipasi Orang Tua dan V Tingkat Motivasi Belajar Siśwa telah dilakukan uji coba terhadap 20 siswa SMU Kristen Makassar

\section{Teknik Pengumpulan Data}

Dalam rangka memperoleh data yang akurat dari variable yang dikaji dalam penelitian ini, peneliti menggunakan beberapa teknik pengumpulan data, yaitu:

1. Teknik Wawancara

Teknik wawancara, termasuk instrumen non tes adalah cara untuk mendapatkan Informasi dengan cara bertanya langsung kepada informan. Pendapat Sudjana dan Ibrahim (2001) wawancara adalah alat pengumpul data digunakan untuk mendapatkan Informasi yang berkenaan dengan pendapat, aspirasi, keinginan, keyakinan dan lain-lain dari individu atau responden dilakukan secara lisan.

2. Teknik Dokumentasi

Menurut Arikunto (1999) teknik dokumentasi adalah mencari data atau hal-hal yang berupa catatan, transkrip, buku, surat kabar, majalah, prasasti, notulen, agenda dan sebagainya. Dari pengertian menjadi tersebut maka teknik dokumentasi (non tes) adalah cara untuk mendapatkan Informasi dari dokumen yang berupa catatan-catatan resmi yang menjadi sumber data. 


\section{E. HASIL PENELITIAN DAN PEMBAHASAN}

\section{Deskripsi Variabel Prestasi Belajar, Tingkat Partisipasi Orang Tua dan \\ Motivasi Belajar Siswa}

Deskripsi data yang diperoleh dari lapangan dimaksudkan untuk mengetahui gambaran secara umum mengenai responden yang berkenaan dengan objek penelitian. Pada bagian ini akan disajikan data hasil penelitian meliputi: persentase, rata-rata, median, modus, range dan standar deviasi.

\section{Deskripsi Prestasi Belajar Siswa}

Untuk melihat prestasi belajar siswa diperoleh dari nilai murni siswa kelas 3 (tiga) pada cawu l (satu tahun pelajaran 2003/2004 dari enam mata pelajaran yang menjadi focus penelitian. Keenam mata pelajaran tersebut adalah Matematika, Bahasa Indonesia, Bahasa Inggris, PPKn, Sejarah dan Pendidikan agama.

Tabel 1

\begin{tabular}{|c|l|c|c|}
\hline No & Kategori & Frekuensi & Persentasi \\
\hline 1. & Sangat Rendah (SR) & 5 & 7 \\
2. & Rendah (R) & 16 & 22,53 \\
3. & Sedang (S) & 31 & 43,66 \\
4. & Tinggi(T) & 14 & 19,71 \\
5. & SangatTinggi (ST) & 5 & 7 \\
\hline & Jumlah & 71 & 100 \\
\hline
\end{tabular}

Dari tabel di atas dapat dikatakan bahwa lebih dari 50 persen tingkat prestasi belajar siswa berada pada kategori sedang dan rendah, sehingga dapat dikatakan bahwa tingkat prestasi belajar siswa SMU Kristen Makassar secara keseluruhan masih tergolong sedang. Ini berarti bahwa sebagian besar siswa, belum mampu menyerap materi pelajaran dengan baik. Hal ini menunjukkan bahwa prestasi belajar siswa SMU Kristen Makassar secara umum perlu ditingkatkan.

a. Jenis Kelamin

Dari data yang telah dihimpun dari responden, yang terpilih jadi sampel wanita sebanyak 43 siswa atau sebesar 60.6 persen dan sebanyak 28 siswa atau sebesar 39,4 persen berjenis kelamin laki-laki.

Dari data tersebut dapat diketahui gambaran Tingkat Prestasi Belajar Siswa Berdasarkan jenis kelamin dapat diketahui bahwa sebanyak 16 responden wanita atau 22,4 persen memperoleh nilai termasuk pada kategori sangat tinggi dan tinggi, yang termasuk pada kategori sedang dan rendah sebanyak 16 responden. Sedangkan sebanyak 3 responden laki laki atau 4,2 persen yang memperoleh kategori sangat tinggi dan tinggi. Dengan demikian dapat dikatakan bahwa wanita mempunyai prestasi lebih unggul dibandingkan laki-laki. Tingginya prestasi belajar siswa wanita ditunjukkan oleh adanya nilai yang lebih tinggi dari nilai siswa laki-laki. Ini dapat dikatakan bahwa jenis kelamin memiliki hubungan dengan tingkat prestasi belajar. 
b. Asal Sekolah Lanjutan Tingkat Pertama

Ditinjau dari asal Sekolah Lanjutan Tingkat Pertama (SLTP), gambaran tingkat prestasi belajar siswa dapat diketahui bahwa masing-masing siswa baik yang berasal dari SMP ada pada kategori sedang dengan jumlah 13 atau 18,3 persen.

Hasil penelitian Ghozali (2000) yang menemukan bahwa, prestasi belajar ikut dipengaruhi oleh prestasi akademik awal. Hal ini dapat dipahami bahwa prestasi belajar siswa tidak dipengaruhi oleh lembaga namun dipengaruhi oleh kemampuan siswa atau prestasi belajar sebelumnya.

Menurut data yang dihimpun dari orang tua siswa, tingkat pendidikan orang tua siswa (ayah dan ibu) dapat digolongkan menjadi tiga tingkatan yaitu: 1). Tingkat dasar meliputi Sekolah Dasar dan SLTP; 2). Tingkat menengah meliputih SMU/SMK dan Keagamaan; 3). Pendidikan Tinggi mencakup Sarjana Muda, D3 dan Sarjana..

Tabel. 2

Tingkat prestasi belajar berdasarkan tingkat pendidikan ayah

\begin{tabular}{|l|c|c|c|c|c|c|c|c|}
\hline \multirow{4}{*}{ Kategori } & \multicolumn{7}{|c|}{ Tingkat Dasar Pendidikan Ayah } \\
\cline { 2 - 9 } & \multicolumn{3}{|c|}{ Dasar } & \multicolumn{2}{|c|}{ Menengah } & \multicolumn{2}{c|}{ Tinggi } & \multicolumn{2}{|c|}{ Jumlah } \\
\cline { 2 - 9 } Sangat Rendah & $\mathrm{f}$ & $\%$ & $\mathrm{f}$ & $\%$ & $\mathrm{f}$ & $\%$ & $\mathrm{f}$ & $\%$ \\
\cline { 2 - 9 } & 3 & 4,2 & 2 & 2,8 & - & - & 5 & 7 \\
Rendah & 9 & 12,7 & 5 & 7 & 2 & 2,8 & 16 & 22,6 \\
Sedang & 19 & 26,8 & 9 & 11,3 & 3 & 4,2 & 31 & 43,7 \\
Tinggi & 13 & 18,3 & & - & 1 & 1,4 & 14 & 19,7 \\
Sangat Tinggi & - & - & 4 & 5,6 & 1 & 1,4 & 5 & 7 \\
\hline Jumlah & 44 & 62 & 20 & 28.2 & 7 & 9.2 & 71 & 100 \\
\hline
\end{tabular}

Jika dilihat frekuensi masing-masing kategori, mengindikasikan tingkat pendidikan orang tua (ayah) tidak menunjukkan adanya perbedaan tingkat prestasi belajar siswa. Hal ini tidak sejalan dengan hasil penelitian Supriyadi (1994) yang mengatakan bahwa tingkat pendidikan ayah memberikan kontribusi atau pengaruh terhadap prestasi belajar siswa.

\section{Tabel.3}

Tingkat prestasi belajar berdasarkan tingkat pendidikan ibu

\begin{tabular}{|l|r|r|c|c|c|c|c|c|}
\hline \multirow{4}{*}{ Kategori } & \multicolumn{8}{|c|}{ Tingkat Dasar Pendidikan Ayah } \\
\cline { 2 - 10 } & \multicolumn{3}{|c|}{ Dasar } & \multicolumn{2}{c|}{ Menengah } & \multicolumn{2}{c|}{ Tinggi } & \multicolumn{2}{c|}{ Jumlah } \\
\cline { 2 - 10 } Sangat Rendah & $\mathrm{f}$ & $\%$ & $\mathrm{f}$ & $\%$ & $\mathrm{f}$ & $\%$ & $\mathrm{f}$ & $\%$ \\
\cline { 2 - 10 } Rendah & 2 & 2,8 & 3 & 4,2 & 0 & 0 & 5 & 7 \\
Sedang & 12 & 16,4 & 4 & 5,6 & 0 & 0 & 16 & 22,6 \\
Tinggi & 26 & 36,6 & 4 & 5,6 & 1 & 1,4 & 31 & 43,7 \\
Sangat Tinggi & 10 & 14,1 & 4 & 5,6 & 0 & 0 & 14 & 19,7 \\
\hline Jumlah & 2 & 2,8 & 2 & 2,8 & 1 & 1,4 & 5 & 7 \\
\hline
\end{tabular}


c. Pekerjaan Orang Tua

Menurut jenis pekerjaan orang tua siswa, data yang dihimpun dari responden dapat dikelompokkan menjadi tiga yaitu: 1) Pegawai Negeri meliputi: Pegawai, Guru, ABRI dan POLRI; 2) Wiraswasta/swasta meliputi: dagang, pegawai perusahaan swasta; 3) tani baik tani tambak maupun tani sawah atau kebun.

\section{Deskripsi Tingkat Partisipasi Orang Tua Menurut Persepsi Siswa}

Dari data yang diperoleh, tingkat partisipasi orang tua menurut persepsi siswa termasuk pada kategori sangat tinggi dalam arti mendekati nilai sempurna hanya 9 responden atau 12,68 persen, kategori tinggi sebanyak 18 responden atau 25.35 persen, kategori sedang sebanyak 21 responden atau 29.58 persen; kategori rendah sebanyak 17 responden atau 23.94 persen dan kategori sangat rendah sebesar 8.45 persen. Sehingga secara berurutan dapat diketahui tingkat kategori mulai dari yang tertinggi sampai yang terendah yaitu: kategori tinggi, kategori rendah kemudian kategori sangat tinggi dan yang terakhir kategori sangat rendah.

Tabel.4

Tingkat Partisipasi Orang Tua

\begin{tabular}{|l|l|c|c|}
\hline No. & Kategori & Frekuensi & Persentase \\
\hline 1 & Sangat Rendah (SR) & 7 & 9,86 \\
2 & Rendah (R) & 15 & 21,36 \\
3 & Sedang (S) & 27 & 38,03 \\
4 & Tiinggi(T) & 16 & 22,53 \\
5 & Sangat Rendah (SR) & 6 & 8,45 \\
\hline & Jumlah & 71 & 100 \\
\hline
\end{tabular}

3. Deskripsi Tingkat Motivasi Belajar siswa

Berdasarkan hasil analisis deskripsi, diperoleh skor tingkat motivasi belajar siswa maksimum 79, skor minimum 59, skor rata-rata 69.2l, standar deviasi 3.84, mudus 71 dan median 69. Ini menunjukkan skor yang paling banyak pada Posisi di atas rata-rata lebih sedikit. Jika dilihat dari standar deviasi maka variabilitas skor yang diperoleh cukup kecil atau tidak lebih dari sepertiga rangenya.

Darigambaran tersebut dapat diperoleh Informasi bahwa tingkat motivasi belajar siswa sebagian besar tergolong kategori sedang. Dengan demikian motivasi belajar siswa masih perlu ditingkatkan. Untuk lebih jelasnya dapat dilihat pada tabel berikut.

Tabel 5

Tingkat Motivasi Belajar Siswa

\begin{tabular}{|l|l|c|c|}
\hline No & \multicolumn{1}{|c|}{ Kategori } & Frekuensi & Persentase \\
\hline I & Sangat Rendah (SR) & 4 & 5,64 \\
2 & Rendah (R) & 14 & 19,72 \\
3 & Sedang & 34 & 47,89 \\
4 & Tinggi (T) & II & 15,49 \\
5 & Sangat Tinggi (ST) & 8 & 11,26 \\
\hline & Jumlah & 71 & 100 \\
\hline
\end{tabular}


Analisis Inferensial Tentang Pengaruh Partisipasi Orang Tua dan Motivasi Belajar Siswa Terhadap Prestasi Belajar

Berdasarkan hasil analisis statistik variable partisipasi orang tua $(\mathrm{Xl})$ dan motivasi belajar (X2) terhadap prestasi belajar (Y) dengan menggunakan analisis regresi ganda pada taraf signifikansi $\bullet=0.05$ diperoleh nilai koefisien regresi sebesar 790.776 di mana lebih besar dari F tabel 0.05, 2.68=3.14 nilai ini menunjukkan adanya pengaruh yang signifikan. Dengan demikian Berdasarkan hasil analisis dapat dikatakan bahwa adanya pengaruh yang signifikan tingkat partisipasi orang tua dan tingkat motivasi belajar siswa terhadap prestasi belajar atau dapat dikatakan bahwa partisipasi orang tua dan motivasi belajar sebagai variable bebas mempengaruhi prestasi belajar sebagai variabel terikat.

Sehingga dari hasil analisis tersebut diperoleh nilai koefisien diterminasi (R2) sebesar 0.96. Dari angka tersebut menunjukkan bahwa di antara variasi total prestasi belajar yang dapat dijelaskan bersama-sama oleh variable bebas yaitu partisipasi orang tua dan motivasi belajar adalah sebesar 96 persen. Dengan demikian Hipotesis yang diajukan adalah "terdapat pengaruh partisipasi orang tua dan motivasi belajar siswa bersama-sama terhadap prestasi belajar diterima".

Selanjutnya untuk mengetahui seberapa besar sumbangan masing-masing variable bebas terhadap variable terikat dapat diketahui dari nilai $R 2$ pada analisis regresi sederhana. Sedang untuk mengetahui sumbangan relatif besarnya sumbangan masing-masing variabel bebas terhadap variabel terikat dalam pembahasan dapat dilihat dari persentase sumbangan relatif(SR) dan persentase sumbangan efektif(SE).

Dari hasil analisis diketahui bahwa partisipasi dari orang tua dan motivasi belajar memberikan sumbangan yang positif terhadap prestasi belajar. Hal ini dapat dipahami bahwa kedua variable tersebut merupakan predictor yang baik terhadap prestasi belajar.

\section{Pembahasan hasil Penelitian}

Hasil penelitian ini menunjukkan bahwa secara umum tingkat prestasi belajar siswa SMU Kristen Diakui Makassar secara kualitatif termasuk pada kategori sedang. Hasil temuan ini membuktikan bahwa siswa SMU Kristen Makassar belum dapat menyerap materi pelajaran yang diperoleh di sekolah dengan baik. Ini berarti penguasaan pengetahuan/ keterampilan yang dikembangkan setiap mata pelajaran, yang lazim diketahui dari nilai tes atau nilai yang diberikan oleh guru belum menampakkan hasil yang baik. Ini mengindikasikan perlu adanya upaya-upaya ke arah peningkatan yang berkaitan dengan prestasi belajar.

Prestasi belajar pada dasarnya merupakan indikator keberhasilan atau kualitas dan pengetahuan yang telah dikuasai siswa. Di sisi lain prestasi belajar merupakan hasil dari suatu sistem pendidikan, sehingga tingkat keberhasilannya ditentukan dan dipengaruhi oleh elemenelemen dari sistem itu sendiri seperti raw input, Instrumental input dan environmental input. Menurut pendapat Tirtaraharja (2000) bahwa pendidikan merupakan sistem yang saling berkaitan antara masukan mentah (row input), masukan instrumental (Instrumental input) dan masukan lingkungan (environmental input), yang masing-masing masukan saling mempengaruhi keberhasilan pendidikan.

Hal tersebut senada dengan Sudjana (1988) bahwa hasil belajar di sekolah 70 persen, dipengaruhi oleh kemampuan siswa sendiri dan 30 persen dipengaruhi oleh lingkungan. 
Demikian juga menurut Munandar (1999) menyatakan bahwa prestasi belajar dipengaruhi oleh intelegensi, motivasi dan tingkat kecerdasan. Lebih lanjut mengatakan bahwa prestasi belajar merupakan perwujudan dari bakat dan kemampuan. Kemampuan yang dimaksudkan adalah sebagai daya motif untuk melakukan suatu tindakan.

Hasil analisis infrensial menunjukkan pengaruh yang signifikan tingkat partisipasi orang tua dan motivasi belajar terhadap prestasi belajar siswa SMU Kristen Diakui Makassar. Hal ini sesuai dengan hasil penelitian yang dilakukan oleh Firdaus dkk. (2000) bahwa partisipasi orang tua dalam pelaksanaan pendidikan secara sangat meyakinkan berpengaruh positif terhadap prestasi belajar siswa dan menunjukkan semakin tinggi keterlibatan dan kepedulian terhadap masalah-masalah pendidikan di sekolah, semakin meningkat pula prestasi siswa dalam mata setiap pelajaran.

Partisipasi orang tua dalam pendidikan anak pada dasarnya keterlibatan baik secara mental maupun fisik dan bertanggung jawab atas keberhasilan pendidikan anaknya. Hasil analisis menunjukkan bahwa tingkat partisipasi orang tua menurut persepsi siswa kaitannya terhadap prestasi belajar siswa SMU Kristen Makassar masih berada pada kategori sedang. Gambaran tersebut menunjukkan bahwa belum semua orang tua sebagaimana yang dipersepsikan anak/siswa, memahami arti pentingnya partisipasi dapat meningkatkan keberhasilan pendidikan anaknya di sekolah. Apabila hal ini dibiarkan sudah barang tentu akan mempengaruhi hasil belajar siswa. Oleh karena itu pemahaman akan arti pentingnya partisipasi orang tua perlu ditanamkan pada orang tua. Untuk hal tersebut perlu perhatian yang serius baik dari pihak sekolah, dari pihak pemerintah, masyarakat dan khususnya dari pihak orang tua itu sendiri.

Hasil analisis ini mengindikasikan bahwa partisipasi orang tua kaitannya dengan keberhasilan pendidikan siswa SMU Kristen Makassar belum memberikan hasil yang optimal. Hal ini menunjukkan dari pilihan jawaban yang diberikan oleh siswa dalam instrumen penelitian bahwa sebagian besar siswa memberikan nilai pada kategori sedang. Gambaran tersebut atas dasar tinjauan dari empat dimensi sebagaimana penjelasan pada deskripsi hasil penelitian.

Orang tua yang memahami akan pentingnya pendidikan anak, cenderung akan selalu memperhatikan, segala sesuatu yang menjadi kebutuhan anaknya dalam hal pendidikan, seperti memenuhi biaya-biaya yang berkaitan dengan pendidikan termasuk saran prasarana yang diperlukan, mengarahkan termasuk menyuruh, melarang serta menghukum anaknya dan lainlain sebagainya. Hal ini sesuai dengan pendapat Ardana (1986) yang menyatakan bahwa keluarga (orang tua) yang sadar akan makna pendidikan, akan berusaha menciptakan suasana yang kondusif dalam keluarga untuk belajar anaknya. Dan mengusahakan sarana dan prasarana belajar yang,memadai, mengatur dan membimbing kegiatan belajar anaknya sehari-hari yang dapat membantu keberhasilan anak di sekolah, sebaliknya apabila orang tua tidak memperdulikan pendidikan anaknya maka akan menghambat keberhasilan pendidikan anaknya di sekolah.

Partisipasi orang tua dalam memenuhi biaya pendidikan anak dapat dilihat dari jumlah skor yang diperoleh, yaitu sebesar tujuh puluh koma tujuh lima. Ini artinya sebagaian besar siswa memberikan penilaian yang tinggi, sehingga dapat dikatakan bahwa orang tua siswa sangat Memperhatikan dalam hal pemenuhan biaya pendidikan anaknya. Demikian juga pada indikator menyediakan fasilitas dan indikator menciptakan lingkungan belajar. 


\section{KESIMPULAN DAN SARAN}

\section{Kesimpulan}

Berdasarkan pembahasan yang dikemukakan sebelumnya, maka dapat diambil kesimpulan sebagai berikut:

Tingkat Prestasi Belajar siswa SMU Kristen Makassar termasuk dalam kategori sedang. Prestasi belajar merupakan hasil dari proses belajar mengajar, perlu ditingkatkan untuk mencapai tujuan pendidikan.

Tingkat Partisipasi Orang Tua menurut persepsi siswa kaitannya dengan prestasi belajar siswa SMU Kristen Makassar termasuk dalam kategori sedang. Ini menunjukkan bahwa orang tua dalam hal memperhatikan pendidikan anaknya, masih kurang optimal. Oleh karena itu perlu mendapat perhatian dari semua pihak utamanya dari para orang tua sendiri.

Motivasi belajar siswa SMU Kristen Makassar termasuk dalam kategori sedang. Hal ini menunjukkan bahwa perlu adanya upaya-upaya untuk meningkatkan motivasi belajar baik oleh pihak sekolah, orang tua maupun siswa sendiri. Karena motivasi sangat penting dalam kegiatan proses belajar mengajar dalam rangka mencapai hasil atau prestasi belajar yang optimal.

Terdapat pengaruh yang signifikan tingkat partisipasi orang tua dan motivasi belajar terhadap prestasi belajar siswa SMU Kristen Makassar baik secara sendiri-sendiri maupun bersama-sama. Hal ini mengindikasikan bahwajika partisipasi orang tua dan motivasi belajar siswa ditingkatkan maka prestasi belajar siswa juga akan meningkat.

\section{Saran}

Sesuai Kesimpulan yang diuraikan sebelumnya, maka dapat diusulkan saran-saran untuk meningkatkan partisipasi orang tua dan motivasi belajar terhadap prestasi belajar siswa SMU Kristen Makassar.

1. Untuk meningkatkan partisipasi orang tua, hendaknya:

a. Pengelola pendidikan merancang suatu model program pelaksanaan pendidikan yang berorientasi pada hubungan kerja sama sekolah dan masyarakat (orang tua) baik dalam bentuk materi maupun ide-ide atau masukan-masukan dalam rangka meningkatkan mutu pendidikan. Seperti melibatkan orang tua dalam merumuskan berbagai program yang akan dilaksanakan.

b. Orang tua sebagai penanggung jawab pendidikan anak lebih meningkatkan dalam memberikan pengarahan, bimbingannya, dorongan dengan penuh kasih sayang.

c. Guru, terutama wali kelas diharapkan meningkatkan hubungan dengan orang tua siswa dengan memberikan Informasi tentang perkembangan siswa baik secara rutin maupun insidental, terutama bagi siswa yang bermasalah di sekolah.

2. Untuk meningkatkan motivasi belajar siswa, diharapkan kepada:

a. Pengelola pendidikan diharapkan untuk merancang sistem pembelajaran yang dapat merangsan atau meningkatkan motivasi belajar siswa sesuai dengan tingkat motivasi belajar siswa.

b. Guru, mampu menyajikan materi dengan menggunakan metode pemebelajaran yang inovatif, kreatif dan vareatif, sehingga mampu merangsan motivasi belajar, dan diharapkan mampu mengenali tingkat motivasi setiap siswa 
c. Orang tua, dalam memotivasi belajar siswa juga memberikan penghargaan apabila anaknya memperoleh prestasi yang baik dan memberikan peringatan jika melanggar aturan ataupun mendapat prestasi yang rendah. Di samping Memperhatikan baik secara materi, maupun mental spritual.

d. Siswa sendiri, hendaknya menyadari akan pentingnya motivasi, karena dengan motivasi yang tinggi maka akan mendapatkan hasil yang optimal.

3. Disarankan kepada peneliti masalah kependidikan, untuk melakukan penelitian lanjutan, khususnya mengenai prestasi belajar siswa ditinjau dari faktor yang lain.

\section{Daftar Pustaka}

Ardana, Wayan. 1986. Dasar-Dasar Kependidikan, Pengaruh Pendidikan Luar Sekolah Terhadap Pendidikan di Sekolah, Modul 4. Malang: IKIP Fakultas Ilmu Pendidikan.

Arikunto, Suharsimi. 1998. Prosedur Penelitian suatu Pendekatan Praktek. Jakarta: Rineka cipta.

Bukka, Muhammad. 2000. Pengaruh Tes Formatif dan Minat Belajar Terhadap Hasil Belajar Matematika. Disertai UNJ tidak diterbitkan. Ruhama.

Darajat, Zakiah. 1995. Pendidikan islam Dalam Keluarga dan Sekolah. Bandung:

Depdikbud. 1996. Kamus Besar bahasa Indonesia. Edisi Kedua. Jakarta: Balai Pustaka.

Dimyati dan Mudjiono. 1999. Belajar dan Pembelajaran. Jakarta: Rineka Cipta.

Firdaus, dkk. 1999. Pengaruh Partisipasi dan Pola Asuh Orang tua Dalam Pendidikan Terhadap Prestasi Belajar Pendidikan Agama dan Pendidikan Jasmani dan Kesehatan Murid SD di Kota Makassar. Laporan Hasil Penelitian Universitas Negeri Makassar.

Ghozali, Abbas. 2000. Pengaruh Latar Belakang Keluarga dan Faktor Sekolah Terhadap Keberhasilan Lulusan SLTA. Jurnal Pendidikan dan Kebudayaan nomor 024 tahun ke 6.

Goode, William J. Sosiologi Keluarga. Diterjemahkan oleh Lailahanoum Hasyim. 1991. Jakarta: Bumi Aksara.

Koeswara E. 1989. Teori Motivasi dan Aplikasinya. Bandung: Angkasa.

Pidarta, Made. 1997. Peranan Ibu Dalam Pendidikan Anak. Jurnal Ilmu Pendidikan Nopember 1997. Jilid 4 nomor 4

Sahabuddin. 1997. Faktor-Faktor yang menunjang Efektivitas Proses Belajar Mengajar. Naskah disampaikan pada Seminar Akademik IV PGSD D-II FIP IKIP Ujung Pandang.

Sahabuddin. 1999. Mengajar dan Mengajar. Makassar: Badan Penerbit Universitas Negeri Makassar. Persada.

Sardiman. 2000. Interaksi \& Motivasi Belajar MengajarI. Jakarta: Raja Grafindo

Shocib, Muhammad. 1998. Pola Asuh Orang Tua. Jakarta: Rineka Cipta.

Siagian, Sondang, P. 1995. Teori Motivasi dan Aplikasinya. Jakarta: Rineka Cipta.

Slameto. 1995. Belajar dan Faktor-Faktor Yang Mempengaruhinya. Jakarta: nekaCipta

Sudjana, Nana.1995. Penilaian Hasil Belajar. Bandung: Remaja Rosdakarya. Suryosubroto,B.1997. Proses Belajar Mengajar di Sekolah. Jakarta: Rineka Cipta 